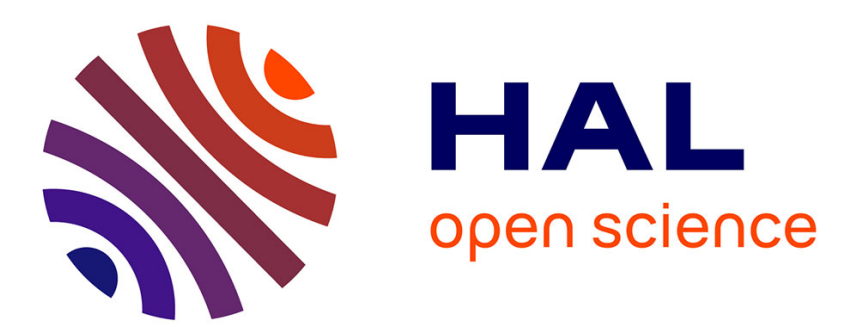

\title{
Filter-feeder macroinvertebrates as key players in culturable bacteria biodiversity control: a case of study with (Polychaeta: Sabellidae)
}

Margherita Licciano, Antonio Terlizzi, Adriana Giangrande, Rosa Anna

Cavallo, Loredana Stabili

\section{To cite this version:}

Margherita Licciano, Antonio Terlizzi, Adriana Giangrande, Rosa Anna Cavallo, Loredana Stabili. Filter-feeder macroinvertebrates as key players in culturable bacteria biodiversity control: a case of study with (Polychaeta: Sabellidae). Marine Environmental Research, 2007, 64 (4), pp.504. 10.1016/j.marenvres.2007.04.004 . hal-00501917

\section{HAL Id: hal-00501917 https://hal.science/hal-00501917}

Submitted on 13 Jul 2010

HAL is a multi-disciplinary open access archive for the deposit and dissemination of scientific research documents, whether they are published or not. The documents may come from teaching and research institutions in France or abroad, or from public or private research centers.
L'archive ouverte pluridisciplinaire HAL, est destinée au dépôt et à la diffusion de documents scientifiques de niveau recherche, publiés ou non, émanant des établissements d'enseignement et de recherche français ou étrangers, des laboratoires publics ou privés. 


\section{Accepted Manuscript}

Filter-feeder macroinvertebrates as key players in culturable bacteria biodiversity control: a case of study with Sabella spallanzanii (Polychaeta: Sabellidae)

Margherita Licciano, Antonio Terlizzi, Adriana Giangrande, Rosa Anna Cavallo, Loredana Stabili

PII: S0141-1136(07)00066-9

DOI: 10.1016/j.marenvres.2007.04.004

Reference: MERE 3119

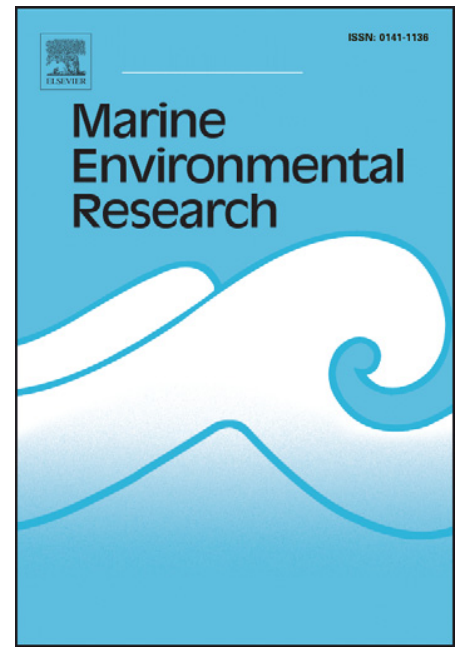

To appear in:

Marine Environmental Research

Received Date:

8 January 2007

Revised Date:

13 April 2007

Accepted Date:

13 April 2007

Please cite this article as: Licciano, M., Terlizzi, A., Giangrande, A., Cavallo, R.A., Stabili, L., Filter-feeder macroinvertebrates as key players in culturable bacteria biodiversity control: a case of study with Sabella spallanzanii (Polychaeta: Sabellidae), Marine Environmental Research (2007), doi: 10.1016/j.marenvres. 2007.04.004

This is a PDF file of an unedited manuscript that has been accepted for publication. As a service to our customers we are providing this early version of the manuscript. The manuscript will undergo copyediting, typesetting, and review of the resulting proof before it is published in its final form. Please note that during the production process errors may be discovered which could affect the content, and all legal disclaimers that apply to the journal pertain. 
Filter-feeder macroinvertebrates as key players in culturable bacteria biodiversity control: a case of study with Sabella spallanzanii (Polychaeta: Sabellidae)

Margherita Licciano ${ }^{1 *}$, Antonio Terlizzi ${ }^{1}$, Adriana Giangrande ${ }^{1}$, Rosa Anna Cavallo ${ }^{2}$ Loredana Stabili $^{1-2}$

${ }^{1}$ Dipartimento di Scienze e Tecnologie Biologiche ed Ambientali (DiSTeBA), Via Prov. LecceMonteroni, 73100-Lecce, Italy

${ }^{2}$ Istituto per l'Ambiente Marino Costiero - Sezione di Taranto - CNR, Via Roma 3, 74100-Taranto, Italy

e-mail: margherita.licciano@unile.it (*author for correspondence)

Keywords: Filter feeders, Polychaeta, culturable heterotrophic bacteria, diversity, Sabella spallanzanii, Mediterranean Sea 


\section{Abstract}

The present study investigates the effect of the filtering activity of Sabella spallanzanii on the culturable heterotrophic bacterial community through the comparison of the bacterial diversity in transplanted polychaetes and the surrounding seawater. For isolation of culturable heterotrophic bacteria, seawater samples as well as polychaete homogenates were plated in triplicates onto Bacto Marine Agar 2216 (Difco). All the colonies grown were isolated, subcultured and identified by several morphological, biochemical and cultural methods. Some bacterial genera showed higher average abundances in polychaetes than in seawater (i.e. Lucibacterium and Photobacterium). Aeromonas represented a conspicuous component of the bacterial community both in $S$. spallanzanii and seawater. The presence of Cytophaga and Pseudomonas was also relevant in the examined seawater samples. The selective concentrations of some bacterial genera inside $S$. spallanzanii either by grazing on bacteria or their capability as bacterial reservoirs, provides evidence for the role of macrobenthic invertebrates as key determinants for microbial diversity. 


\section{Introduction}

Research over the past three decades has dramatically changed views of food web structure in the aquatic ecosystems, establishing the central role of bacteria in the functioning of the microbial loop (Pomeroy, 1974, 1980). Less clear are, however, the mechanisms which regulate the structure of the pelagic microbial food web. Grazing by heterotrophic nanoplankton has been shown to exert a significant pressure on bacterioplankton dynamics in terms of biomass and structure (del Giorgio et al., 1996; Gasol et al., 2002a, 2002b). By contrast, the role of macrobenthic invertebrates feeding on bacteria, coupling the benthic-pelagic system, is only a recently explored issue (Cloern, 1996;

Doering \& Oviatt, 1986; Loo \& Rosenberg, 1989; Petersen \& Riisgård, 1992; Riisgård \& Larsen, 2001a, 2001b).

The impact of macroinvertebrates on bacterial community has been evaluated mainly for molluscan populations. The removal from waters of several species of bacteria by the common mussel Mytilus edulis (L.) and the subsequent fate of some polymers of the bacteria have been investigated by Birkbeck \& McHenery (1982). Moreover, oysters, clams and mussels have been described as reservoirs of vibrios (Cavallo \& Stabili, 2002; Kaspar \& Tamplin, 1993; Kaysner et al., 1989).

The trophic role of bacterioplankton has also been highlighted for other groups of suspension feeders, including polychaetes (Gili \& Coma, 1998; Orejas et al., 2000; Prieur et al., 1990).

Recent field studies conducted on the filter-feeder polychaete Sabella spallanzanii, showed its ability to accumulate and concentrate bacteria from the surrounding environment with a higher efficiency for autochthonous bacteria (Stabili et al., 2006b). Further laboratory experiments carried out on this species demonstrated that bacteria, employed as only food source, were efficiently filtered and retained (Licciano et al., 2005).

Most of the studies on the trophic role of macroinvertebrates focused exclusively on the impact on bacterial abundance. Studies concerning the effects of filter-feeders on bacterial biodiversity are therefore needed, also in consideration of the fact that microbial diversity affects the involvement of bacteria in biogeochemical cycles (Fuhrman et al., 1994; Gonzàles \& Moran, 1997; Rehnstam et al., 
1993). In this framework, both quantitative and qualitative removal throughout the filter-feeding activity of macroinvertebrates may have significant ecological implications.

Taking into account that the qualitative removal throughout the filter-feeding activity of $S$. spallanzanii is completely unexplored, the present study investigates the effects of filtration activity of this species on the culturable heterotrophic bacterial diversity through the comparison of the bacterial community in transplanted polychaetes and the surrounding seawater. It is well known that viable culturable bacteria account only for a small fraction of the total bacterial community and therefore it is not representative of the whole bacteria present in the environment, thus the interpretation of the data inferred from the count of the viable culturable bacteria is obviously constrained (Zweiffel \& Hagström, 1995). However, cultural methods can still provide some information on potential metabolic activity and on the role of heterotrophic bacteria in the biogeochemical cycles (Zaccone et al., 2002). Moreover, several recent studies, using various hybridization protocols, have re-evaluated the role of bacteria able to form colonies on solid media (Fuhrman et al., 1994; Hagström et al., 2000; Pinhassi et al., 1999; Stabili et al., 2006a).

\section{Materials and Methods}

\subsection{Study area and sampling methods}

Sampling was undertaken in March $\left(\mathrm{Ti}_{1}\right)$ and July $2002\left(\mathrm{Ti}_{2}\right)$ at three oligotrophic sites (Lido Silvana $\left(\mathrm{Si}_{1}\right)$, S. Vito $\left(\mathrm{Si}_{2}\right)$, and Lido Gandoli $\left(\mathrm{Si}_{3}\right)$, Northern Ionian Sea, Mediterranean Sea) characterized by similar hydrological features (Fig. 1). More particularly, as measured by a multiparametric sounding-line "Ocean Seven 401" (Jolzonant, Italy), the mean temperature was $19.6 \pm 0.12^{\circ} \mathrm{C}$ at $\mathrm{S}$. Vito, $19.4 \pm 0.13^{\circ} \mathrm{C}$ at Lido Silvana and $19.4 \pm 0.12$ at Lido Gandoli. The mean salinity was about $38 \%$ in the three sites. The oxygen mean percentage saturation was $110.7 \pm 0.48$ at S. Vito, $111.8 \pm 0.43$ at Lido Silvana and 112.6 \pm 0.45 at Lido Gandoli. For each site, water samples were aseptically collected in three replicates using $5 \mathrm{~L}$ Niskin bottles at a depth of $0.5 \mathrm{~m}$. 
Samples were then transferred on ice to the laboratory for isolation of culturable heterotrophic bacteria within $4 \mathrm{~h}$ of sampling.

\subsection{Collection of polychaetes}

Adult specimens of Sabella spallanzanii were collected in the Gulf of Taranto (Italy) at a depth of 5-15 $\mathrm{m}$ by SCUBA divers. In the laboratory, after removal of tube epibionts, worms were placed in a $60 \mathrm{~L}$ tank at a salinity of $37 \%$ in a temperature-controlled room $\left(\mathrm{T}=22^{\circ} \mathrm{C}\right)$. The tank water was aerated and filtered through $0.22 \mu \mathrm{m}$ pore size membranes (Millipore). Specimens were left unfed and acclimatised to these conditions for 2 days before the field studies. $\mathrm{At}^{\mathrm{Ti}} \mathrm{i}_{1}$ (March) as well as $\mathrm{Ti}_{2}$ (July), starved specimens were randomly assigned to 9 groups, each consisting of 10 individuals and suspended in mesh cages (mesh size 10x10 mm) at the three sampling sites (three cages for each site for a total number of 30 worms). After two weeks, specimens were collected together with the water samples.

\subsection{Bacteriological methods}

Bacteriological analyses were performed on seawater from the three sampling sites and on $S$. spallanzanii homogenates (for each cage the whole group of 10 individuals was pooled into one sample) prepared either immediately after the laboratory starvation period or after the field deployment $\left(\mathrm{Ti}_{1}\right.$ and $\left.\mathrm{Ti}_{2}\right)$. In both cases the worms were collected, extracted from the tubes in the laboratory, washed several times with sterile seawater to assure the elimination of any bacteria trapped within the external mucus, and homogenized for $90 \mathrm{~s}$ in a sterile Waring blender. The homogenates (ca.100g) were filtered through sterile gauze, diluted with filtered $(0.22 \mu \mathrm{m})$ seawater to obtain a 1:10 (w/v) dilution and processed in a similar manner to the seawater samples.

For isolation of culturable heterotrophic bacteria, undiluted seawater and serial dilutions of each water sample as well as polychaete homogenate were plated in triplicates onto Bacto Marine Agar 2216 (Difco) (seeding with $0.1 \mathrm{~mL}$ ). The plates were incubated at $22^{\circ} \mathrm{C}$ for 7 days. At the end of the 
incubation period all the colonies (276 from seawater and 161 from polychaetes) were isolated in axenic culture, subcultured and identified by several morphological, biochemical and cultural methods (Holt et al., 1994; Oliver, 1982). The miniaturized identification tests API 20 E and API 20 NE (Biomerieux Sa, France) were used to study the following biochemical characteristics of the isolated strains: hydrolysis of gelatin, nitrate reductase, presence of B-galactosidase, carbohydrate utilization: saccharose, arabinose, mannitol, fructose, glucose, maltose, starch, rhamnose, galactose, mannose, sorbitol, glycerol, urease, indole, $\mathrm{H}_{2} \mathrm{~S}$ and acetoine production, and citrate utilization. To adjust the salinity of the medium to a value more representative of seawater, and work in experimental conditions more adequate to the development of marine bacteria, a $3 \% \mathrm{NaCl}$ solution was added to the suspension medium (Zdanowski \& Figueiras,1999). The galleries were incubated for 2 days at $22^{\circ} \mathrm{C}$ and the API profiles were compared with the Analytical Profile Index database (Apilab Plus, version 3.3.3; Biomerieux). Because of previously reported discrepancies between conventional and commercial assays (Biosca et al., 1993) several tests were re-examined. When necessary, additionally, other biochemical tests were performed. Overall, a total of 19 bacterial groups were identified.

\subsection{Statistical analysis}

The experimental design consisted of 3 factors: Time (Ti, 2 levels, random), Site (Si, 3 levels, namely Lido Gandoli, Lido Silvana and San Vito, random and crossed to Ti) and Polychaetes (Po, 2

levels, i.e. the 1 degree - of - freedom contrast of bacterial contents in polychaetes vs seawater, fixed and crossed to $\mathrm{Ti}$ and $\mathrm{Si}$ ), with $n$ with $=5$ replicates.

The 19 identified bacterial groups were considered as variables in the multivariate dataset, which therefore consisted of 36 samples and 19 variables.

Non-parametric multivariate procedures have been developed in recent years, providing useful statistical tools that have been widely adopted in ecological studies (Clarke 1993). An important feature of these procedures is that they do not rely on the assumption of multivariate normality. This 
is a requirement of traditional multivariate methods such as multivariate analysis of variance (MANOVA), but such an assumption is very unlikely to be met in the vast majority of ecological data sets (Legendre \& Legendre 1998).

Here, tests for the significance of terms involved in the full model were made by using a distancebased permutational multivariate analysis of variance (PERMANOVA; Anderson 2001) based on Bray-Curtis dissimilarities on untransformed data. Each term in the analysis was tested using 4999 random permutations of the appropriate units (Anderson \& ter Braak, 2003). Where the number of possible permutable units was not enough to get a reasonable test by permutation, a $P$-value was obtained using a Monte Carlo random sample from the asymptotic permutation distribution (Anderson \& Robinson, 2003).

If appropriate, terms found to be significant in the full model were examined individually using pair-wise tests using the square root of the PERMANOVA test statistic (a multivariate pseudo ttest) and 4999 random permutations. Multivariate patterns were portrayed by non-metric multidimensional scaling (nMDS) plots.

Similarity percentages (SIMPER) (Clarke, 1993) was used to identify the bacterial taxa most contributing to determine differences between Po and SW bacterial assemblages.

The analyses were done using the PERMANOVA.exe (Anderson, 2005) and PRIMER computer programs (Clarke \& Gorley 2001).

\section{Results}

PERMANOVA highlighted the significance of the interaction term $\mathrm{Ti} \times \mathrm{Si} \times \mathrm{Po}$, suggesting that the differences between polychaetes versus seawater (Po vs SW) bacterial assemblages varied across sites and times of sampling (Table 1). Pairwise comparisons of these differences within each level of the factors $\mathrm{Ti}$ and $\mathrm{Si}$ revealed that in $\mathrm{Ti}_{1}$ (March) significant differences between Po vs $\mathrm{SW}$ were detected only at $\mathrm{Si}_{2}$ (S. Vito). In $\mathrm{Ti}_{2}$ (July), however, differences between Po vs $\mathrm{SW}$ bacterial assemblages were significant at all sites (Table 1). 
nMDS plots (Fig. 2a,b) reflected PERMANOVA outputs: points referring to the bacterial assemblages in polychates were separated from those referring to seawater. From the nMDS plots it was also clear that water samples clustered more closely than points referring to polychaetes which appeared more widespread. Global patterns of differences, therefore, were clearer in $\mathrm{Ti}_{2}$ (Fig. 2b) whereas in $\mathrm{Ti}_{1}$ (Fig. 2a) the variable pattern of differences across sites prevented a clear representation of clusters within bacterial differences Po and SW assemblages.

\subsection{Heterotrophic bacterial diversity}

Among the Gram-negative bacteria, with the exception of Vibrio, Alteromonas and Flexibacter, all the isolated genera were present at $\mathrm{Ti}_{1}$ both in $\mathrm{SW}$ and Po (Table 2). Vibrio and Alteromonas were detected only in polychaetes; by contrast Flexibacter was isolated only from seawater.

Moreover, Cythophaga and Pseudomonas showed higher average abundances in seawater greatly accounting for the differentiation of Po vs SW bacterial assemblages (Table 2). A strong percentage contribution to the dissimilarity between Po vs SW was also provided by Lucibacterium that was more abundant in polychaetes. Gram-positive bacteria (cocci and bacilli) were found to occur with higher average abundances in seawater, contributing to differentiate Po vs SW assemblages (Table 2). At $\mathrm{Ti}_{2}$, among Gram-negative bacteria Moraxella, Aeromonas, Cythophaga, Photobacterium, Pseudomonas and the family of Enterobacteriaceae contributed mostly to the average dissimilarity between Po and SW (Table 2). Aeromonas represented a conspicuous component of the bacterial community both in S. spallanzanii and seawater. The bacterial genera isolated exclusively in polychaete samples were Lucibacterium and Acinetobacter. Photobacterium was more abundant in the polychaete samples. Moraxella and Alcaligenes were recorded only in seawater. Among Grampositive bacteria, bacilli prevailed in seawater samples whilst cocci in polychaetes. SIMPER identified both categories as strongly contributing to the average dissimilarity between Po vs SW.

\section{Discussion}


Previous quantitative laboratory and field studies have demonstrated the capability of Sabella spallanzanii to utilize bacteria as food source as well as its ecological role as reservoir for survival and growth of some bacteria (Licciano et al., 2005; Stabili et al., 2006b).

In the present study we focused on the culturable heterotrophic bacteria diversity in transplanted $S$. spallanzanii and the surrounding seawater. The main separation between seawater vs polychaetes resulted to be significant in both times of sampling even though in the nMDS plots the main effect of differences between seawater $v s$ polychaetes in $\mathrm{T}_{1}$ is not immediately perceived due to the variability among sites. In the nMDS plots the clustering of points referred to polychaete homogenates across the 3 sites appeared more widespread than those referring to seawater. This feature suggests that the sampling site is unlikely to influence the polychaete microbial community which, by contrast, is quite heterogeneous. The filtration process predictably includes periods of inactivity or transition between feeding and inactivity by worms due to the intrusion of the branchial crown within the tube (Licciano et al., 2005). On this basis, we can suggest that the observed heterogeneous microbial community among the individuals of S. spallanzanii could depend either on the ability of this species in regulate its pumping rates and even stop filtering, according to physiological and behavioural needs, or the selective grazing on bacteria. Indeed, several studies estimating clearance rates based on the uptake of different trophic sources have reported a different retention efficiency indicating that macroinvertebrate filter feeders actively select particles (Frost, 1980; Navarro \& Widdows, 1997; Riisgård \& Larsen, 2001b; Shumway et al., 1988; Stabili et al., 2006c).

Two interesting features can be inferred from our data on the culturable bacteria biodiversity:

i)- bacterial genera detected in both polychaetes and seawater.

The analyses of culturable heterotrophic bacterial biodiversity showed that Aeromonas represented a conspicuous component of the bacterial community both in S. spallanzanii and seawater. Aeromonads are inhabitants of aquatic environments and also belong to the flora of fish, amphibia 
and other marine organisms (Kueh \& Chan, 1985; Stabili \& Cavallo, 2004). The presence of Cytophaga and Pseudomonas was also relevant in the examined seawater samples. The enzymatic versatility of these genera is well known and has been suggested as an explanation of their importance in particle turnover (De Long et al., 1993). The isolation of Cytophaga during this study is in good agreement with other studies reporting frequent isolation of the CytophagaFlavobacterium group in marine water (Glöckner et al., 1999). Pseudomonas is often isolated from seawater, sediments, phytoplankton and zooplankton (Nair \& Simidu, 1987).

ii)- selective grazing of bacteria by polychaetes.

Some bacterial genera such as Lucibacterium and Photobacterium, showed higher average abundances in polychaetes than in seawater in both $\mathrm{Ti}_{1}$ and $\mathrm{Ti}_{2}$, whilst Vibrio and Alteromonas only at $\mathrm{Ti}_{1}$ and Acinetobacter at $\mathrm{Ti}_{2}$. Microscope observations are therefore required to assess whether the captured microorganisms were phagocytosed and not yet digested, accounting for the higher average abundances, or whether S. spallanzanii may function as habitat "islands", providing a unique set of environmental conditions for microbial colonization. In this framework, it is worth noting the presence in S. spallanzanii of the luminous bacteria ascribable to Photobacterium and Lucibacterium. Luminous bacteria are common in the marine environment and are isolated as "freeliving bacteria" as well as mutualistic symbioses in the light organs of certain fishes (Baumann \& Baumann, 1984; Nealson et al., 1984; Ruby \& Morin, 1979). These bacteria also occur on the surfaces (saprophytic), in the vital fluids (parasitic) and within the gastrointestinal contents of marine organisms. The ecological role of the relationship between these associated bacterial populations and S. spallanzanii is not known; we could hyphothesize only, as already suggested by Nair \& Simidu (1987) for other marine organisms, that this sabellid may contribute to the survival and distribution of the luminous bacteria in the Northern Ionian Sea, without any inference on the type of association (symbiontic or saprophytic). 
Our results agree with other studies carried out on other filter feeders macroinvertebrates such as mussels and sponges (Stabili et al. 2006c). Laboratory experiments have shown, in fact, that the mussels' filter-feeding activity may exert a control on microbial community in terms of abundance and biodiversity (Kiorboe et al., 1981). Among the few available studies on bivalves, Kueh \& Chan (1985) observed that the most frequently detected microorganisms from Crassostrea gigas were mainly Pseudomonas, Vibrio, Acinetobacter and Aeromonas. Prieur et al. (1990) reported that Photobacterium and Vibrio were more abundant in C. gigas than in the surrounding seawater. Some of the bacterial genera found in our study, such as Aeromonas, Pseudoalteromonas, Pseudomonas, Vibrio, Photobacterium and the family Enterobacteriaceae, were also recently detected in the mussel Mytilus trossulus, (Beleneva et al., 2003). Taylor et al., (2004, 2005) studying the marine sponge-associated bacteria and the potential implications for marine microbial diversity showed that the microbial community in Cymbastela concentrica differed significantly from those found in other sponges, which were more similar to seawater. Kefalas et al., (2003) assessed that the bacterial load in Spongia officinalis extract was greater than that of the proximal seawater providing evidence for the sponge ability to concentrate bacteria in its body. Bacteria identified in the sponge extract belonged to Escherichia, Morganella, Proteus, Pasteurella, Aeromonas, Pseudomonas and Acinetobacter genera.

From present data we can assume that the filtering activity of $S$. spallanzanii results in higher average abundances of some bacteria genera inside the worms showing the role of this polychaete in determining microbial diversity. Estimates of total marine microbial diversity are usually mostly based on planktonic or sediment communities (Curtis et al., 2002; Hagström et al., 2002; Torsvik et al., 2002) with less emphasis on potential associations with macroinvertebrates. By contrast, these organisms can represent very different habitats from those in the plankton or sediments and they may retain the ingested bacteria thus harbouring a greater diversity of microbes. Moreover, dense populations of benthic filter-feeders could be very effective against some types of microorganisms or completely ineffective against others. This, in turn can play a significant role in separating 
bacterial niches and reducing competition among bacteria in the environment (Kefalas et al., 2003;

Prins et al., 1998; Taylor et al., 2005; Thoms et al., 2003).

Deriving global diversity estimates from measures of $S$. spallanzanii impact on microbial diversity is clearly speculative. However, taking into account that there are more than 200,000 species of marine eukaryotes (Ormond et al., 1997), if even a small percentage reflects the pattern observed for the investigated polychaete, we can assume that macrobenthic invertebrates either grazing on bacteria or functioning as bacterial reservoirs may have potential ecological implications, playing a role as key determinant for microbial diversity. As a consequence, macroinvertebrates control an extremely active process of oxidation of organic matter in the ecosystem (Cloern, 1996; Doering \& Oviatt, 1986; Widdows et al., 1998) taking into account that culturable bacteria are the most active actors in performing the oxidation of organic matter in aquatic systems (Ostroumov, 2005) and that different bacteria, exhibiting different ectohydrolytic enzyme profiles, are able to degrade different organic compounds.

\section{References}

Anderson, M.J. (2001). A new method for non-parametric multivariate analysis of variance. Australian Journal of Ecology, 26, 32-46.

Anderson, M.J. (2005). PERMANOVA: a FORTRAN computer program for permutational multivariate analysis of variance. Department of Statistics, University of Auckland, New Zealand. http://www.stat.auckland.ac.nz/ mja/Programs.htm.

Anderson, M.J., \& Robinson, J. (2003). Generalised discriminant analysis based on distances. Australian \& New Zealand Journal of Statistics 45, 301-318.

Anderson, M.J., \& ter Braak, C.J.F. (2003). Permutation tests for multi-factorial analysis of variance. Journal of Statistical Computation and Simulation, 73, 85-113. 
Baumann, P., \& Baumann, L. (1984). Genus II. Photobacterium Beijerinck 1889. In N. R. Kreig, \& J. G. Holt, Bergey's Manual of Systematic Bacteriology, vol. I, Williams \& Wilkins, Baltimore.

Beleneva, I.A., Zhukova, N.V., \& Maslennikova, E.F. (2003). Comparative study of microbial communities from cultured and natural populations of the mussel Mytilus trossulus in Peter the Great Bay. Microbiology, 72(4), 472-477.

Biosca, E.G., Garay, E., \& Amaro, C. (1993). Evaluation of the API 20E system for identification and discrimination of Vibrio vulnificus biotypes 1 and 2. Journal of Fish Diseases, 16, 79-82.

Birkbeck, T.H., \& Mc Henery, J.G. (1982). Degradation of bacteria by Mytilus edulis. Marine Biology, 72, 7-15.

Cavallo, R.A., \& Stabili, L. (2002). Presence of vibrios in seawater and Mytilus galloprovincialis (Lam.) from the Mar Piccolo of Taranto (Ionian Sea). Water Research, 36, $3719-3726$.

Clarke, K.R. (1993). Non-parametric multivariate analyses of changes in community structure. Australian Journal of Ecology, 18, 117-143.

Clarke, K.R., \& Gorley, R.N. (2001). PRIMER v5: User Manual/Tutorial. Primer-e, Plymouth, United Kingdom.

Cloern, J.E. (1996). Phytoplankton bloom dynamics in coastal ecosystems. A review with some general lessons from sustained investigation of San Francisco Bay, California. Reviews of Geophysics, 34, 127-168.

Curtis, T.P., Sloan, W.T., \& Scannell, J.W. (2002). Estimating prokaryotic diversity and its limits. Proceedings of the National Academy of Sciences USA, 99, 10494-10499.

De Long, E.F., Franks, D.G., \& Alldredge, A.L. (1993). Phylogenetic diversity of aggregateattached vs. free-living marine bacterial assemblages. Limnology and Oceanography, 38, 924-934. 
del Giorgio, P.A., Gasol, J.M., Vaqué, D., Mura, P., Agustì, S., \& Duarte, C. (1996). Bacterioplankton community structure: protists control net production and the proportion of active bacteria in a coastal marine community. Limnology and Oceanography, 41(6),11691179.

Doering, P.H., \& Oviatt, C.A. (1986). Application of filtration rate models to field populations of bivalves: an assessment using experimental mesocosms. Marine Ecology Progress Series, $31,265-275$.

Frost, T.M. (1980). Clearance rate determinations for the fresh-water sponge Spongilla lacustris: effects of temperature, particle type and concentration, and sponge size. Archiv fuer Hydrobiologie, 90, 330-356.

Fuhrman, J.A., Lee, S.H., Masuchi, Y., Davis, A.A., \& Wilcox, R.M. (1994). Characterization of marine prokaryotic communities via DNA and RNA. Microbial Ecology, 28, 133-145.

Gasol, J.M., Pedrós-Alió, C., \& Vaqué, D. (2002a). Regulation of bacterial assemblages in oligotrophic plankton systems: results from experimental and empirical approaches. Applied Environmental Microbiology, 81, 435-452.

Gasol, J.M., Šimek, K., Kojecka, P., Comerma, M., Garcia, J.C., Casamayor, E.O., \& Armengol, J. (2002b). A transplant experiment to identify the factors controlling bacterial abundance, activity, production and community composition in a eutrophic canyon-shaped reservoir. Limnology and Oceanography, 47, 62-77.

Gili, J.M., \& Coma, R. (1998). Benthic suspension feeders: their paramount role in littoral marine food webs. Trends in Ecology and Evolution, 13, 316-321.

Glöckner, F.O., Fucus, B.M., \& Amann, R. (1999). Bacterioplankton composition of Lakes and Oceans: a first comparison based on fluorescence in situ ibridation. Applied and Environmental Microbiology, 65(8), 3721-3726. 
Gonzàles, J.M., \& Moran, M.A. (1997). Numerical dominance of a group of marine bacteria in the alpha-subclass of the class Proteobacteria in coastal seawater. Applied and Environmental Microbiology, 63, 4237-4242.

Hagström, A., Pinhassi, J., \& Zweifel, U.L. (2000). Biogeographical diversity among marine bacterioplankton. Aquatic Microbial Ecology, 21, 231-244.

Hagström, A., Pommier, T., Rohwer, F., Simu, K., Stolte, W., Svensson, D., \& Zweifel, U.L. (2002). Use of $16 \mathrm{~S}$ ribosomal DANN for the lineation of marine bacterioplankton species. Applied Environmental Microbiology, 68, 3628-3633.

Holt, J.G., Kreig, N.R., Sneath, P.H. A., \& Staley, J.T. (1994). Bergey's manual of determinative bacteriology $9^{\text {th }}$ ed. Williams $\&$ Wilkins, Baltimore.

Kaspar, C.W., \& Tamplin, M.L. (1993). Effects of temperature and salinity on the survival of Vibrio vulnificus in seawater and shellfish. Applied Environmental Microbiology, 59, 24252429.

Kaysner, C.A., Tamplin, M.L., Wekell, M.W., Stott, R.F., \& Colburn, K.G. (1989). Survival of Vibrio vulnificus in shellstock and oyster (Crassostrea gigas and Crassostrea virginica) and effects of isolation medium on recovery. Applied Environmental Microbiology, 5, 30723079.

Kefalas, E., Castritsi-Katharios, J., \& Miliou, H. (2003). Bacteria associated with the sponge Spongia officinalis as indicators of contamination. Ecological Indicators, 2, 339-343.

Kiorboe, T., Mohlenberg, F., \& Nohr, O. (1981). Effect of suspended bottom material on growth and energetics in Mytilus edulis. Marine Biology, 61, 283-288.

Kueh, C.S., \& Chan, K.J. (1985). Bacteria in bivalve shellfish with special reference to the oyster. Journal of Applied Bacteriology, 59, 41-47.

Licciano, M., Stabili, L., \& Giangrande, A. (2005). Clearance rates of Sabella spallanzanii and Branchiomma luctuosum (Annelida:Polychaeta) on a pure culture of Vibrio alginolyticus. Water Research, 39(18), 4375-4384. 
Loo, L.O., \& Rosenberg, R. (1989). Bivalve suspension-feeding dynamics and benthic pelagic coupling in an eutrophicated marine bay. Journal of Experimental Marine Biology and Ecology, 130, 253-276.

Nair, S., \& Simidu, U. (1987). Distribution and significance of heterotrophic marine bacteria with antibacterial activity. Applied Environmental Microbiology, 53, 2957-2962.

Navarro, J.M. \& Widdows, J. (1997). Feeding physiology of Cerastoderma edule in response to a wide range of seston concentrations. Marine Ecology Progress Series, 152, 175-186.

Nealson, H.K., Haygood, G.M., Tebo, M.B., Roman, M., Miller, E., \& McCoster, E.J. (1984). Contribution by symbiontically luminous fishes to the occurrence and bioluminescence of luminous bacteria in seawater. Microbial Ecology, 10, 69-77.

Oliver, J.D. (1982). Taxonomic scheme for the identification of marine bacteria. Deep Sea Research, 29, 795-798.

Orejas, C., Gili, J.M., Arntz, W.E., Ros, J.D., López, P.J., Teixidó, N., \& Filipe, P. (2000). Benthic suspension feeders, key players in Antarctic marine ecosystems? Contributions to Science 1(3), 299-311.

Ormond, R.F.G., Gage, J.D., \& Angel, M.V. (1997). Marine biodiversity: patterns and processes. Cambridge University Press, Cambridge.

Ostroumov, S.A. (2005). Some aspects of water filtering activity of filter-feeders. Hydrobiologia, 542, 275-286.

Petersen, J.K., \& Riisgård, H.U. (1992). Filtration capacity of the ascidian Ciona intestinalis and its grazing impact in a shallow fjord. Marine Ecology Progress Series, 88, 9-17.

Pinhassi, J., Azam, F., Hemphälä, J., Long, R.A., Martinez, J., Zweifel, U.L., \& Hagström, Å. (1999). Coupling between bacterioplankton species composition, population dynamics, and organic matter degradation. Aquatic Microbial Ecology, 17, 13-26.

Pomeroy, L.R. (1974). The ocean's food web, a changing paradigm. Biological Science, 24, 499-504. 
Pomeroy, L.R. (1980). Microbial roles in aquatic foodwebs. In: R. R. Colwell, J. Foster, Aquatic Microbial Ecology (pp 85-109). College Park, Maryland: Sea Grant University.

Prieur, D., Mével, G., Nicolas, J.L., Plusquellec, A., \& Vigneulle, M. (1990). Interactions between bivalve molluscs and bacteria in the marine environment. Oceanography and Marine Biology - an Annual Review, 28, 277-352.

Prins, T.C., Smaal, A.C., \& Dame, R.F. (1998). A review of the feedbacks between bivalve grazing and ecosystem processes. Aquatic Ecology, 31, 349-359.

Rehnstam, A.S., Bäckman, S., Smith, D.C., Azam, F., \& Hagström, Å. (1993). Blooms of sequence-specific culturable bacteria in the sea. FEMS Microbiology Ecology, 102, 161166.

Riisgård, H.U., \& Larsen, P.S. (2001a). Comparative ecophysiology of active zoobenthic filterfeeding, essence of current knowledge. Journal of Sea Research, 44, 169-193.

Riisgård, H.U., \& Larsen, P.S. (2001b). Minireview: ciliary filter feeding and bio-fluid mechanics - present understanding and unsolved problems. Limnology and Oceanography, 46(4), 882-891.

Ruby, E.G., \& Morin, J.G. (1979). Luminous enteric bacteria of marine fishes: A study of their distribution densities and dispersion. Applied Environmental Microbiology, 38, 406-411.

Shumway, S.E:, Bogdanowicz, C. \& Dean, D. (1988). Oxygen consumptionand feeding rates of the sabellid polychaete, Myxicola infundibulum (Renier). Comparative Biochemistry and Physiology, 90A(3), 425-428.

Stabili, L., \& Cavallo, R.A. (2004). Biodiversity of culturable heterotrophic bacteria in the Southern Adriatic Sea Italian coastal waters. Scientia Marina, 68(1), 31-41.

Stabili, L., Caroppo, C. \& Cavallo, R.A. (2006a). Monitoring of a coastal mediterranean area: culturable bacteria, phytoplankton, environmental factors and their relationships in the southern adriatic sea. Environmental Monitoring and Assessment, 121, 303-325. 
Stabili, L., Licciano, M., Giangrande, A., Fanelli, G., \& Cavallo, R.A. (2006b). Sabella spallanzanii filter-feeding on bacterial community: ecological implications and applications. Marine Environmental Research, 61(1), 74-92.

Stabili, L., Licciano, M., Giangrande, A., Longo, C., Mercurio, M., Nonnis Marzano, C. \& Corriero. G. (2006c). Filtering activity of Spongia officinalis var. adriatica (Schmidt) (Porifera, Demospongiae) on bacterioplankton: implications for bioremediation of polluted seawater. Water Research, 40, 3083-3090.

Taylor, M.W., Schupp, P.J., Dahllöf, I., Kjellberg, S., \& Steinberg, P.D. (2004). Host specificity in marine sponge-associated bacteria, and potential implications for marine microbial diversity. Environmental Microbiology, 6(2), 121-130.

Taylor, M.W., Schupp, P.J, de Nys, R., Kjellberg, S., \& Steinberg, P.D. (2005). Biogeography of bacteria associated with the marine sponge Cymbastela concentrica. Environmental Microbiology, 7(3), 419-433.

Thoms, C., Horn, M., Wagner, M., \& Hentschel, U. (2003). Monitoring microbial diversity and natural product profiles of the sponge Aplysina cavernicola following transplantation. Marine Biology, 142, 685-692.

Torsvik, V., Øvreas, L., \& Thingstad, T.F. (2002). Prokaryotic diversity-magnitude dynamics and controlling factors. Science, 296, 1064-1066.

Widdows, J., Brinsley, M.D., Salkeld, P.N. \& Elliott, M. (1998). Use of annular flumes to determine the influence of current velocity and bivalves on material flux at the sedimentwater interface. Estuaries, 21, 552-559.

Zaccone, R., Caruso, G., \& Calì, C. (2002). Heterotrophic bacteria in the northern Adriatic Sea: seasonal changes and ectoenzyme profile. Marine Environmental Research, 54, 1-19.

Zdanowski, M.K., \& Figueiras, F.G. (1999). CFU bacterial fraction in the estuarine upwelling ecosystem of Ria de Vigo, Spain: variability in abundance and their ecophysiological description. Marine Ecology Progress Series, 182, 1-15. 
Zweifel, U.L. Hagström, A. (1995). Total counts of marine bacteria include a large fraction of non-nucleoid-containing bacteria (ghosts). Applied and Environmental Microbiology, 61(6), $2180-2185$ 


\section{Figure captions}

Figure 1. Map of the Northern Ionian Sea indicating the three sampling sites.

Figure 2. Non-metric multidimensional scaling (nMDS) plots on the basis of the Bray-Curtis dissimilarities between bacterial assemblages in seawater (SW) and S. spallanzanii (Po) at each of the 2 sampling times.

$\mathrm{Si}=$ site; $\mathrm{LS}=$ Lido Silvana; $\mathrm{SV}=\mathrm{San}$ Vito; $\mathrm{LG}=$ Lido Gandoli; 
ACCEPTED MANUSCRIPT

21

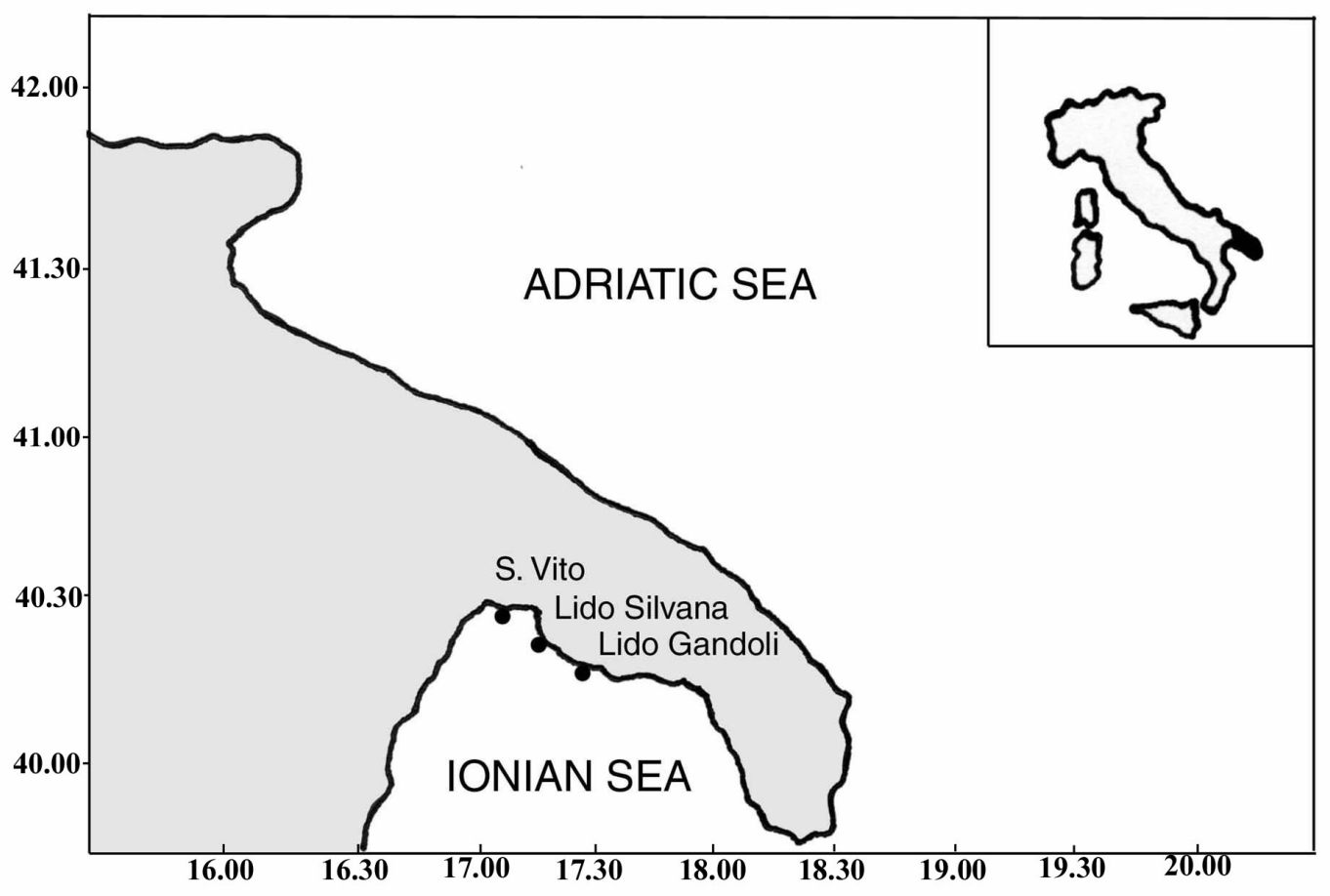

Fig. 1 

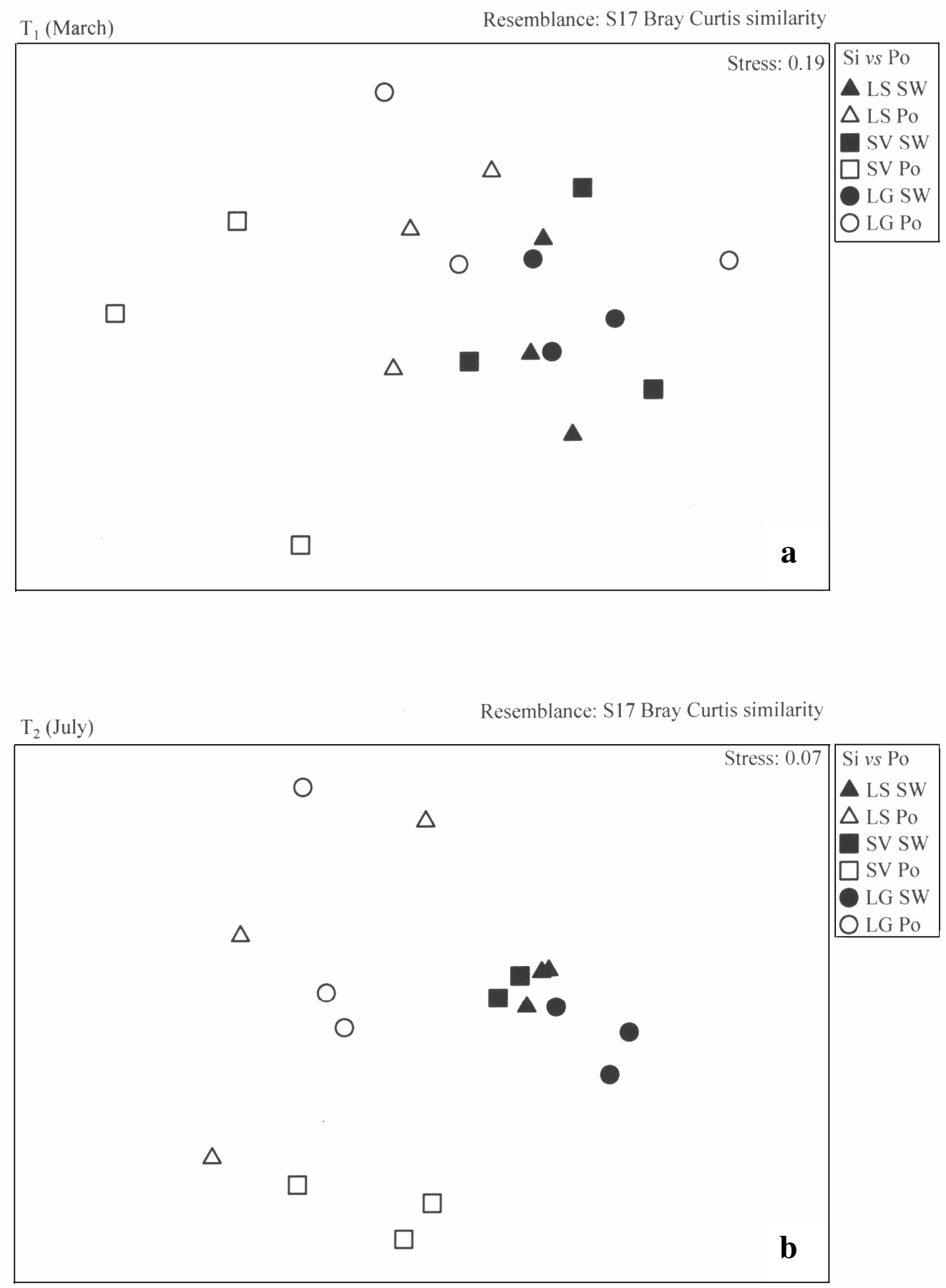

Fig. 2 
Table 1 Results of PERMANOVA testing for differences in bacterial assemblages in polychaetes (Po) vs seawater (SW) across the three sites in time. Given the significance of the interaction term $\mathrm{Ti} \times \mathrm{Si} \times \mathrm{Po}$ the analysis is followed by pairwise comparisons of bacterial assemblages in Po $v s \mathrm{SW}$ at each level of the Ti and Si terms (see text for further details)

\begin{tabular}{lccccc}
\hline Source & $\begin{array}{c}\text { Sum of } \\
\text { Squares }\end{array}$ & $\begin{array}{c}\text { Degrees of } \\
\text { freedom }\end{array}$ & $\begin{array}{c}\text { Mean } \\
\text { Squares }\end{array}$ & F ratio & P(perm) \\
\hline Time $=\mathrm{Ti}$ & 7418.2078 & 1 & 7418.2078 & & \\
$\mathrm{Site}=\mathrm{Si}$ & 5151.8617 & 2 & 2575.9309 & & \\
Polychaetes = Po & 12674.1527 & 1 & 12674.1527 & & \\
$\mathrm{Ti} \times \mathrm{Si}$ & 3753.7746 & 2 & 1876.8873 & & \\
$\mathrm{Ti} \times \mathrm{Po}$ & 3037.3550 & 1 & 3037.3550 & & \\
$\mathrm{Si} \times \mathrm{Po}$ & 5876.5201 & 2 & 2938.2600 & & \\
$\mathrm{Ti} \times \mathrm{Si} \times \mathrm{Po}$ & 4650.5582 & 2 & 2325.2791 & 2.1941 & 0.0110 \\
$\mathrm{Residual}$ & 25434.5457 & 24 & 1059.7727 & & \\
Total & 67996.9758 & 35 & & & \\
\hline
\end{tabular}

\begin{tabular}{lcccccc}
\hline & LS & SV & LG \\
\hline $\mathrm{T}_{1}$ (March) & $t=1.5270$ & $P=0.1088$ & $t=1.9492$ & $P=0.0350$ & $t=1.1334$ & $P=0.3180$ \\
$\mathrm{~T}_{2}$ (July) & $t=2.0253$ & $P=0.0448$ & $t=4.0303$ & $P=0.0060$ & $t=3.6258$ & $P=0.0044$
\end{tabular}

LS= Lido Silvana; SV= San Vito; $\mathrm{LG}=$ Lido Gandoli 
Table 2 Output of SIMPER analysis: average abundance (AvAb) of bacterial genera contributing the most to the Bray-Curtis dissimilarity (data untransformed) values between seawater (SW) vs polychaetes (Po) groups in each of the two sampling times. For each of SW and Po groups data have been pooled across the three sites. The percentage contribute that each variable made to the observed value of dissimilarity is reported in the Contrib \% column

\begin{tabular}{lllllll}
\hline \multicolumn{7}{c}{ Ti $_{\mathbf{1}}$ (March) } \\
Bacterial genera & AvAb SW & AvAb Po & Contrib \% & AvAb SW & AvAb Po & Contrib \% \\
\hline Moraxella & 0.89 & 0.89 & 6.94 & 2.00 & 0.00 & 13.05 \\
Aeromonas & 2.00 & 1.89 & 10.16 & 4.00 & 2.78 & 12.97 \\
Cytophaga & 3.44 & 0.11 & 21.85 & 2.22 & 0.22 & 12.96 \\
Photobacterium & 0.11 & 0.22 & 1.79 & 1.22 & 2.22 & 10.69 \\
Enterobacteriaceae & 0.78 & 0.67 & 5.21 & 2.00 & 0.44 & 10.00 \\
Pseudomonas & 2.00 & 0.67 & 11.75 & 1.67 & 0.22 & 9.92 \\
Flavobacterium & 0.44 & 0.67 & 4.59 & 0.44 & 0.22 & 3.01 \\
Lucibacterium & 0.11 & 1.00 & 6.47 & 0.00 & 0.33 & 2.17 \\
Flexibacter & 0.11 & 0.00 & 0.67 & 0.22 & 0.11 & 2.00 \\
Acinetobacter & 0.67 & 0.56 & 4.67 & 0.00 & 0.22 & 1.47 \\
Alcaligenes & 0.22 & 0.22 & 2.55 & 0.22 & 0.00 & 1.25 \\
Vibrio & 0.00 & 0.11 & 0.76 & 0.11 & 0.11 & 0.70 \\
Alteromonas & 0.00 & 0.11 & 0.94 & - & - & - \\
Agrobacterium & 0.11 & 0.11 & 1.15 & - & - & - \\
Chromobacterium & 0.67 & 0.67 & 4.61 & - & - & 12.03 \\
Gram-positive (bacilli) 1.44 & 0.78 & 9.06 & 2.11 & 0.33 & 7.75 \\
Gram-positive (cocci) & 1.00 & 0.56 & 6.82 & 0.56 & 1.44 & \\
\hline
\end{tabular}

$\mathbf{T i}_{1}$ (March): Average Bray-Curtis dissimilarity between Po vs $\mathrm{SW}=67.41$

$\mathbf{T i}_{2}$ (July): Average Bray-Curtis dissimilarity between Po vs $\mathrm{SW}=60.41$ 